\title{
Pengaruh Suplementasi Moringa oleifera terhadap Performa Produksi Sapi Peranakan Ongole
}

\section{(Effect of Moringa oleifera Supplementation on the Performance of Sapi Peranakan Ongole)}

\author{
Firdaus F, Luthfi M, Affandhy L \\ Loka Penelitian Sapi Potong, Jl. Pahlawan No. 2 Grati, Pasuruan, Jawa Timur Kode Pos 67184 \\ firdausfrediansyah@gmail.com
}

\begin{abstract}
The study aimed to determine the level of Moringa oleifera (MO) flour to maintain the performance of sapi pejantan Peranakan Ongole as fresh semen producers. The feed given has a maximum content of DM 3\% BW and CP 11\%. The study used eight PO bull with an initial body weight of $558.63 \pm 127.29 \mathrm{~kg}$ aged $3-5$ years. The experimental design was designed using two treatments with four replications. The treatment given was vitamin A, E, mineral Zinc, and 100 grams/head/day of MO flour supplementation (P1) and vitamin A, E, mineral Zinc, and 50 grams/head/day of MO flour supplementation (P2). The parameters observed were feed consumption (dry matter, crude protein, crude fiber, total digestible nutrient $(\mathrm{TDN})$ ), average daily gain (ADG), body condition score (BCS), linear body (hearth girth, body length, wither height), and scrotum circumference. Data were analyzed using the t-test. The results showed that there were no significant differences between the two levels of MO flour giving to feed consumption (DM, CP, CF, TDN, ADG, BCS, linear body (hearth girth, body length, wither height), and scrotum circumference. Decreases in BCS values and scrotum circumference were seen in $\mathrm{P} 1$, whereas in $\mathrm{P} 2$ showed positive growth in all body size and scrotum circumference parameters. It was concluded that P2 could be used as supplementation to have a positive impact on the scrotum circumference without a decrease in the production performance and linear growth of body weight of PO bulls.
\end{abstract}

Key words: Peranakan Ongole, Moringa oleifera, feed, production, bulls

\begin{abstract}
ABSTRAK
Penelitian bertujuan untuk mengetahui level pemberian tepung Moringa oleifera (MO) untuk mempertahankan performa produksi sapi pejantan Peranakan Ongole (PO) sebagai penghasil semen segar. Pakan yang diberikan sebanyak maksimal BK 3\% BB dengan kadar PK 11\%. Penelitian menggunakan delapan ekor pejantan sapi PO dengan bobot badan awal $558,63 \pm 127,29 \mathrm{~kg}$ berumur 3-5 tahun. Rancangan percobaan didesain menggunakan dua perlakukan dengan empat ulangan. Perlakuan yang diberikan adalah suplementasi vitamin A, E, mineral Zn and tepung MO sebanyak 100 gram/ekor/hari (P1) dan suplementasi vitamin A, E, mineral Zn dan tepung MO sebanyak 50 gram/ekor/hari (P2). Parameter yang diamati adalah konsumsi pakan (berat kering, protein kasar, serat kasar, total digestible nutrient (TDN)), pertambahan bobot badan harian (PBBH), body condition score (BCS), linear tubuh (lingkar dada, panjang badan, tinggi pundak), dan lingkar scrotum. Data dianalisis menggunakan t-test. Hasil penelitian menunjukkan bahwa tidak terdapat perbedaan nyata diantara dua level pemberian tepung MO terhadap konsumsi pakan (berat kering, protein kasar, serat kasar, total digestible nutrient), $\mathrm{PBBH}, \mathrm{BCS}$, linear tubuh (lingkar dada, panjang badan, tinggi pundak), dan lingkar scrotum pejantan sapi PO. Penurunan nilai BCS, dan lingkar scrotum tampak pada P1, sedangkan pada P2 memperlihatkan pertumbuhan positif
\end{abstract}


pada semua parameter ukuran tubuh dan lingkar skrotum. Disimpulkan bahwa P2 dapat digunakan sebagai suplementasi untuk memberikan dampak positif terhadap lingkar scrotum tanpa terjadi penurunan pada performa produksi dan pertumbuhan linear tubuh sapi PO.

Kata kunci: Peranakan Ongole, Moringa oleifera, pakan, produksi, pejantan

\section{PENDAHULUAN}

Performa produksi sapi potong terutama sapi pejantan yang digunakan sebagai pemacek pada program kawin alam atau sebagai sumber semen salah satu diantaranya adalah manajemen pakan. Pakan menduduki kontribusi tertinggi dalam manajemen pemeliharaan sapi potong sebesar 70\%, untuk mempertahankan kestabilan performa tubuh maupun lingkar scrotum yang bisa mempengaruhi sapi pejantan sebagai sumber semen. Permasalahan yang sering dihadapi umumnya adalah keterbatasan jumlah pemberian pakan yang ditandai dengan rendahnya jumlah pemberian berat kering (BK) dan kandungan nutrient protein kasar (PK) dikaitkan dengan menurunnya performa tubuh yang berakibat pula pada menurunnya performa reproduksi seperti penurunan berat testis, motilitas sperma dan konsentrasi sperma (Barth et al. 2008). Wiyatna et al. (2012) melaporkan bahwa konsumsi BK ransum sapi Peranakan Ongole (PO) di usaha peternakan rakyat di Kabupaten Sumedang sebesar 1,27\% BB dengan hasil PBBH 0,25 kg/ekor/hari, rendahnya konsumsi pakan disebabkan peternak melakukan usaha sapi potong sebagai usaha sambilan dan keterbatasan peternak dalam menyediakan pakan. Diperlukan inovasi teknologi dengan penambahan suplementasi pakan untuk meningkatkan libido dan kualitas semen tanpa mengganggu performa produksi dan ukuran-ukuran tubuh sapi.

Hua-Wei et al. (2011) melaporkan bahwa aditif pakan herbal dapat meningkatkan fungsi kekebalan tubuh, antioksidan, antimikroba dan efek pertumbuhan pada ternak. Herbal yang dapat digunakan salah satunya adalah Moringa oleifera (MO). MO merupakan tanaman daerah tropis yang berpotensi sebagai suplemen pakan ternak. Produksi biomasa MO adalah 4,2-8,2 ton BK/ha berpotensi melengkapi suplementasi pakan komplit untuk ternak (Nouman et al. 2014). MO kaya akan asam amino, asam lemak, mineral dan vitamin untuk menunjang keseimbangan nutrisi ternak. MO memiliki kandungan BK 88,16\%, PK 25,70\%, LK 10,20\%, SK 9,48\%, Abu 13,06\%, Ca 3,34\% dan P 0,39\% Zn 31,03 mg/kg (Syarifuddin et al. 2017) Mg 0,5\%, K 1,5\%, Na 0,164\%, S 0,63\%, Cu 8,25\%, Mn 86,8 mg/kg, Se $363 \mathrm{mg} / \mathrm{kg}$, vitamin E $77 \mathrm{mg} / 100$ gram (Moyo et al. 2011). Mandal et al. (2007) melaporkan bahwa diet zinc 32,5 mg/kg BK pada sapi potong cukup untuk mendukung pertumbuhan dan pencernaan yang normal, dimana respon imun yang lebih baik terjadi ketika Zn propionate ditambahkan ke diet. Mineral Zn berfungsi menstimulir sel leidig pada testis untuk memproduksi hormon testosteron sehingga merangsang terjadinya libido. MO juga memiliki kandungan fenolik yang tinggi dan sifat antioksidan yang kuat dengan nilai IC50 adalah 2.151,3 ppm (Yuliani et al. 2015).

Salah satu usaha yang telah dilakukan dengan menambahkan pakan tambahan berbahan lokal yang mudah didapat berupa tanaman herbal dalam rangka mengatasi permasalahan kekurangan pakan sapi pejantan yang bisa berpengaruh terhadap performa produksi yang berakibat rendahnya produksi semen. Oleh karena itu penelitian ini dilakukan dengan tujuan untuk mengevaluasi diet yang tersedia secara lokal yang dirancang untuk mengoptimalkan performa produksi sapi PO pejantan melalui suplementasi tepung MO. 


\section{MATERI DAN METODE}

Penelitian dilakukan di kandang percobaan Loka Penelitian Sapi Potong (Lolitsapi) mulai Juli 2018 - Oktober 2018. Analisis pakan dilakukan di Laboratorium Nutrisi, Lolitsapi. Penelitian menggunakan delapan ekor sapi PO jantan dengan bobot badan awal rata-rata 558,63 $\pm 127,29 \mathrm{~kg}$ dengan kisaran umur 3-5 tahun. Penimbangan tubuh dilakukan sebanyak 2 (dua) minggu sekali selama tiga bulan. Pakan basal yang diberikan setiap harinya untuk setiap ekor sapi PO dalam bentuk segar, yaitu rumput gajah $15 \mathrm{~kg}$, daun gamal 1,5 kg, dan konsentrat $9 \mathrm{~kg}$. Penelitian menggunakan dua perlakukan dan empat ulangan. Kelompok kontrol (P1) diberikan suplementasi vitamin A (3.900 IU/kg $\mathrm{BK}$ ), vitamin E (60 IU/kg BK), mineral Zn (30 mg/kg BK) dan tepung MO 100 gram/ekor/hari dan kelompok perlakukan (P2) diberikan suplementasi vitamin A (3.900 $\mathrm{IU} / \mathrm{kg} \mathrm{BK}$ ), vitamin E (60 IU/kg BK), mineral Zn (30 mg/kg BK) dan tepung MO 50 gram/ekor/hari. Masing-masing ternak diberikan identitas berupa eartag.

Pakan dan suplementasi diberikan setiap hari selama tiga bulan. Parameter yang diamati adalah konsumsi pakan (berat kering (BK), protein kasar (PK), serat kasar (SK), total digestible nutrient (TDN)), pertambahan bobot badan harian (PBBH), body condition score (BCS), linear tubuh (lingkar dada (LD), panjang badan (PB), tinggi pundak (TP)), dan lingkar scrotum. Konsumsi pakan ditimbang setiap hari selama 3 (tiga) bulan. Bobot badan (kg) diperoleh dengan cara menimbang bobot hidup menggunakan timbangan digital berkapasitas 1000 kg; sedangkan untuk linear tubuh dilakukan dengan cara : 1) LD diperoleh dengan cara melingkarkan pita ukur pada bagian dada dibelakang punuk; 2) data PB (cm) diperoleh dengan cara mengukur jarak dari bongkol bahu (tuberositas humeri) sampai ujung tulang duduk (tuber ischia), menggunakan tongkat ukur; 3) data TP (cm) diperoleh dengan cara mengukur jarak dari permukaan tanah yang rata sampai bagian tertinggi pundak melewati bagian scapula secara tegak lurus, menggunakan tongkat ukur (Zurahmah \& The 2011; SNI 7651.5:2015) dan 4) BCS menggunakan skala 1 - 9 (Herd \& Sprott 1986).

Data dianalisis menggunakan uji-t dengan bantuan SPSS for Windows version 23 (Sugiyono \& Susanto 2015).

\section{HASIL DAN PEMBAHASAN}

\section{Performa produksi}

Performa produksi sapi PO yang diberikan perlakukan P1 dan P2 disajikan pada Tabel 1. Hasil penelitian menunjukkan bahwa bobot badan, konsumsi BK, konsumsi PK, konsumsi SK, konsumsi TDN, dan PBBH antara P1 dan P2 tidak berbeda nyata ( $\mathrm{P}>0,05)$. Hal ini memperlihatkan level suplementasi Moringa oleifera memperlihatkan hasil yang sama terhadap performa produksi antar kedua perlakuan.

Rata-rata PBBH sapi PO pada P1 dan P2 sama, yaitu 0,48 $\pm 0,31$ dan 0,50 kg/ekor. PBBH dipengaruhi oleh ketersediaan dan konsumsi pakan. Rata-rata konsumsi BK, PK, SK dan TDN sapi PO pada P1 dan P2 dalam penelitian ini tidak berbeda nyata ( $\mathrm{P}>0,05)$, sehingga menyebabkan $\mathrm{PBBH}$ juga tidak berbeda nyata. Hasil penelitian ini sama dengan yang dilaporkan oleh Rasyid \& Luthfi (2017) bahwa sapi pejantan PO umur 24-36 bulan dengan pemberian pakan 3\% BK menghasilkan PBBH 0,5 $\pm 0,08 \mathrm{~kg} / \mathrm{ekor}$. PBBH dalam penelitian ini lebih rendah daripada yang dilaporkan oleh Lestari et al. (2011), PBBH sapi PO pejantan yang mengkonsumsi BK 2,11\% BB menghasilkan PBBH sebesar 0,78 $\pm 0,30$ kg. Konsumsi BK pada penelitian ini sebesar 12,01-12,03 kg lebih besar daripada standar 
BCNRM (2018), sapi potong dengan bobot badan 550-600 kg membutuhkan konsumsi BK sebesar 10,98-11,75 kg untuk mendapatkan PBBH 0,5 kg/ekor/hari.

Tabel 1. Rata-rata bobot badan, konsumsi pakan dan PBBH sapi PO penelitian

\begin{tabular}{lrr}
\hline \hline \multirow{2}{*}{ Parameter } & \multicolumn{2}{c}{ Perlakuan (rataan \pm SD) } \\
\cline { 2 - 3 } & \multicolumn{1}{c}{ P1 } \\
\hline Bobot badan awal (kg) & $555,75 \pm 118,94$ & \multicolumn{1}{c}{ P2 } \\
Bobot badan akhir (kg) & $581,50 \pm 123,82$ & $588,50 \pm 146,74$ \\
Konsumsi Berat Kering (BK) (kg) & $12,03 \pm 0,35$ & $12,01 \pm 0,31$ \\
Konsumsi Protein Kasar (PK) (kg) & $1,29 \pm 0,04$ & $1,29 \pm 0,04$ \\
Konsumsi Serat Kasar (SK) (kg) & $2,08 \pm 0,06$ & $2,08 \pm 0,05$ \\
Konsumsi Total Digestible Nutrient (TDN) (kg) & $7,66 \pm 0,23$ & $7,65 \pm 0,21$ \\
Pertambahan bobot badan harian (kg/ekor/hari) & $0,48 \pm 0,31$ & $0,50 \pm 0,24$ \\
\hline
\end{tabular}

P1 = vitamin A, E, Zinc, tepung MO 100 gram; P2 = vitamin A, E, Zinc, tepung MO 50 gram

Perbedaan PBBH dapat disebabkan karena adanya perbedaan manajemen pemberian pakan, umur, jenis kelamin dan bobot badan (Huyen et al. 2011). PBBH terjadi apabila ternak mampu mengubah zat-zat nutrisi yang diperoleh menjadi produk ternak seperti lemak dan daging, setelah kebutuhan pokok terpenuhi. Terjadinya kenaikan PBBH menunjukkan suplementasi MO hingga 100 g/ekor/hari yang memiliki aktivitas zat anti nutrisi tannin (Meigara et al. 2016) sebesar 3,12 mg/g (Moyo et al. 2011) tidak mengganggu sapi PO jantan dalam memenuhi kebutuhan pokok. Senyawa sekunder tanaman seperti tanin tidak menimbulkan gangguan kecernaan ransum pada taraf rendah (Suharti et al. 2009). Rivera-Mendez et al. (2016) mengamati peningkatan pertambahan bobot harian pada sapi pejantan sebesar 1,5 kg/ekor/hari yang disuplementasi tannin terkondensasi hingga 0,6\% BK pakan.

Konsumsi PK P1 dan P2 tidak berbeda nyata ( $\mathrm{P}>0,05)$, semakin tinggi kandungan protein ransum, maka akan semakin tinggi konsumsi proteinnya. Konsumsi PK pada penelitian ini sebesar 1,29 $\pm 0,04 \mathrm{~kg}$ lebih besar dari standar BCNRM (2018) pada sapi potong pejantan dengan bobot badan 550-600 kg membutuhkan konsumsi PK 0,77-0,80 kg. Konsumsi protein yang lebih tinggi dari kebutuhan ternak tidak lebih meningkatkan PBBH. Hal ini karena PBBH tidak hanya berasal dari deposisi protein, tapi juga deposisi lemak (Adiwinarti et al. 2011).

Konsumsi TDN harian pada P1 dan P2 tidak berbeda nyata $(\mathrm{P}>0,05)$ dikarenakan konsumsi BK relatif sama dan kandungan TDN pakan relatif sama sehingga konsumsi TDN juga sama. Konsumsi TDN pada penelitian ini sebesar 7,65-7,66 kg lebih besar dari standar BCNRM (2018), sapi potong dengan bobot badan 550-600 kg membutuhkan konsumsi TDN sebesar 6,06-6,48 kg.

\section{Linear tubuh}

Pengaruh tepung MO terhadap BCS, ukuran tubuh dan lingkar scrotum dapat dilihat pada Tabel 2. Sapi jantan PO pada umur 3-5 tahun masih menunjukkan adanya pertambahan ukuran tubuh (lingkar dada, panjang badan, tinggi pundak). Hasil penelitian menunjukkan bahwa level pemberian tepung MO pada P1 dan P2 tidak berbeda nyata 
terhadap BCS, ukuran-ukuran tubuh dan lingkar scrotum ( $\mathrm{P}>0,05)$. Penurunan skor BCS terjadi pada P1, sedangkan pada P2 menunjukkan peningkatan skor BCS.

Tabel 2. Body condition score dan linear tubuh sapi PO penelitian

\begin{tabular}{llrr}
\hline \hline \multirow{2}{*}{ Parameter } & Periode & \multicolumn{2}{c}{ Perlakuan } \\
\cline { 3 - 4 } & & \multicolumn{1}{c}{ P1 } \\
\hline \multirow{2}{*}{ BCS } & Awal & $7,00 \pm 0,41$ & $6,50 \pm 0,41$ \\
& Akhir & $6,88 \pm 0,25$ & $7,00 \pm 0,91$ \\
\multirow{2}{*}{ Lingkar dada $(\mathrm{cm})$} & Awal & $194,50 \pm 9,15$ & $191,00 \pm 17,61$ \\
& Akhir & $200,50 \pm 11,39$ & $199,75 \pm 15,95$ \\
Panjang badan $(\mathrm{cm})$ & Awal & $147,50 \pm 11,00$ & $147,50 \pm 4,80$ \\
& Akhir & $151,25 \pm 9,32$ & $159,75 \pm 9,84$ \\
Tinggi pundak $(\mathrm{cm})$ & Awal & $140,25 \pm 3,86$ & $141,00 \pm 9,76$ \\
& Akhir & $140,38 \pm 3,77$ & $143,75 \pm 5,33$ \\
Lingkar scrotum $(\mathrm{cm})$ & Awal & $38,25 \pm 3,20$ & $35,00 \pm 2,16$ \\
& Akhir & $37,50 \pm 3,00$ & $35,75 \pm 2,63$ \\
\hline
\end{tabular}

P1 = vitamin A, E, Zinc, tepung MO 100 gram; P2 = vitamin A, E, Zinc, tepung MO 50 gram

Rata-rata pertambahan lingkar dada harian (PLDH) dalam penelitian ini P1 sebesar $0,06 \mathrm{~cm}$ dan P2 sebesar 0,090 cm. Hasil penelitian menunjukkan bahwa kedua level suplementasi tepung MO tidak menunjukkan perbedaan yang signifikan. Rata-rata PLDH sapi PO dalam penelitian ini hampir sama dengan yang dilaporkan oleh Adiwinarti et al. (2005) sebesar 0,09 cm/hari dan Lestari et al. (2010) 0,075 cm/hari dan Adiwinarti et al. (2011) 0,12-0,19 cm/hari. Perbedaan ini kemungkinan disebabkan perbedaan pakan yang diberikan dan umur sapi.

Rata-rata pertambahan tinggi pundak (PTPH) dalam penelitian ini sebesar P1 0,0013 $\mathrm{cm} /$ hari dan P2 0,03 cm/hari. Suplementasi tepung MO dengan level yang berbeda tidak berpengaruh nyata terhadap tinggi pundak $(\mathrm{P}>0,05)$. Diprediksi bahwa pertumbuhan pundak sapi PO pada umur 3-5 tahun telah mencapai pertumbuhan maksimal, sehingga pertambahan tinggi pundak tidak terlihat nyata. Rata-rata PTPH dalam penelitian ini lebih rendah daripada PTPH hasil penelitian Lestari et al. (2010) sebesar 0,054 cm/hari, dan Adiwinarti et al. (2011) sebesar 0,08 cm. Hasil ini dimungkinkan karena umur sapi yang digunakan dalam penelitian ini adalah 3-5 tahun, dibandingkan dengan umur sapi yang digunakan sebagai materi penelitian Adiwinarti et al. (2011) berkisar 1-1,5 tahun.

Rata-rata pertambahan panjang badan harian (PPBH) pada penelitian ini sebesar P1 0,04 cm dan P2 0,13 cm. Panjang badan tidak dipengaruhi oleh gemuk atau kurusnya seekor ternak, namun dipengaruhi oleh tulang kerangka tubuhnya (Adiwinarti et al. 2011). Diprediksi pertambahan panjang tulang harian pada ternak relatif menurun dengan semakin meningkatnya umur ternak. Rata-rata $\mathrm{PPBH}$ pada penelitian ini lebih tinggi daripada hasil penelitian Lestari et al. (2010) pada sapi PO sebesar 0,054 cm dan Adiwinarti et al. (2011) sebesar 0,09 cm. Diduga perbedaan umur sapi dan jenis pakan yang diberikan mempengaruhi perbedaan PPBH sapi PO.

Diameter lingkar scrotum P1 menunjukkan skor yang relatif menurun, Sedangkan P2 menunjukkan peningkatan ukuran. Diduga pemberian tepung Mo dengan level 100 G/Ekor/Hari melebih dosis optimal untuk mendukung pertumbuhan optimal lingkar 
scrotum sebagai salah satu kriteria libido dan kualitas semen pejantan. Saputra et al. (2017) melaporkan bahwa lingkar scrotum memiliki efek yang sangat signifikan $(\mathrm{P}<0,01)$ terhadap volume semen, konsentrasi sperma dan motilitas semen pada sapi Bali. Suplementasi Mo dapat meningkatkan kadar testosteron dalam plasma, libido, dan motilitas sperma pejantan sapi Bali (Syarifuddin et al. 2017).

\section{KESIMPULAN}

Disimpulkan pemberian pakan dengan kandungan BK 3\% BB dan PK 11\% BK sudah memenuhi kebutuhan hidup pokok dan produksi berdasarkan perolehan PBBH dan peningkatan ukuran-ukuran tubuh sapi PO pejantan. Suplementasi tepung MO hingga 50 gram/ekor/hari tidak memberikan pengaruh terhadap besarnya lingkar scrotum tanpa memberikan dampak negatif terhadap performa tubuh sapi PO.

\section{UCAPAN TERIMA KASIH}

Terima kasih kami sampaikan kepada Balitbangtan Kementan yang telah memberikan bantuan dana pada penelitian ini dan semua tim peneliti dan teknisi Lolitsapi (Dian Ratnawati, Dyah Tuwi Ramsiati, Dadang Karnadi), serta tim analisis Labotorium Nutrisi dan kandang percobaan Lolitsapi yang telah membantu terlaksananya kegiatan penelitian dan penulisan makalah ini.

\section{DAFTAR PUSTAKA}

Adiwinarti R, Fariha UR, Lestari CMS. 2011. Pertumbuhan sapi Jawa yang diberi pakan jerami padi dan konsentrat dengan level protein berbeda. JITV. 16:260-265.

Adiwinarti R, Lestari CMS, Vergianti DHS. Pemanfaatan jerami padi fermentasi untuk pakan sapi Peranakan Ongole dan Peranakan Limousin. Prosiding Sem Nasional AINI. hlm. 118-125.

Barth AD, Brito LFC, Kastelic JP. 2008. The effect of nutrition on sexual development of bulls. Theriogenology. 70:485-494.

Beef Cattle Nutrition Series (BCNRM). 2018. Part 3: Nutrient requirement tables (2018 revised). University of Arkansas, United States Departement of Agriculture and Country Government Cooperating.

Herd DB, Sprott LR. 1986. Body condition, nutrition and reproduction of beef cows. Texas Agricultural Extension Service. B-1526.

Hua-wei L, Jian-ming T, Dao-wei Z. 2011. Utilization of Chinese herbal feed additives in animal production. CMS. 10:1262-1272.

Huyen LTT, Herold P, Markemann A, Zarate AV. 2011. Resource use cattle performance and output patterns on different farm types in a mountainous province of Northern Vietnam. Anim Prod Sci. 51:650-661.

Lestari CMS, Adiwinarti S, Arifin M, Purnomodadi A. 2011. The performance of Java and Ongole Crossbred bull under intensive feeding management. J Indones Trop Anim Agric. 36:109-113.

Lestari CMS, Adiwinarti R, Perwitasari D. 2010. Pertumbuhan sapi pernakan limousine dan peranakan ongole jantan yang dipelihara secara intensif. Prosiding Seminar Nasional 
Perspektif Pengembangan Agribisnis Peternakan di Indonesia. Banyumas (Indonesia): Universitas Jenderal Soedirman. hlm. 272-276.

Mandal GP, Dass RS, Isore DP, Garg AK, Ram GC. Effect of zinc supplementation from two sources on growth, nutrient utilization and immune response in male crossbred cattle (Bos indicus $\times$ Bos taurus) bulls. Anim Feed Sci Technol. 138:1-12.

Meigara KM, Mudianta IW, Martiningsih NW. Skrining fitokimia dan uji aktivitas antioksidan ekstrak aseton daun kelor (Moringa oleifera). Wahana Matematika dan Sains. 10:1-11.

Moyo B, Masika PJ, Hugo A, Muchenje V. 2011. Nutritional characterization of Moringa (Moringa oleifera Lam.) leaves. Afr J Biotechnol. 10:12925-12933.

Nouman W, Basra SMA, Siddiqui MT, Yasmeen A, Gull T, Alcayde MAC. 2014. Potential of Moringa oleifera L. as livestock fodder crop: a review. Turk J Agric. 38:1-14.

Rasyid A, Luthfi M. 2017. Uji performa calon bibit sapi Peranakan Ongole berdasarkan karakteristik kuantitatif dan kualitatif. Dalam: Puastuti W, Muharsini S, Inounu I, Tiesnamurti B, Kusumaningtyas E, Wina E, Herawati T, Hartati, Hutasoit R, penyunting. Prosiding Seminar Nasional Teknologi Peternakan dan Veteriner. Bogor (Indonesia): Pusat Penelitian dan Pengembangan Peternakan. hlm.70-77.

Rivera-Mendez C, Plascencia A, Torrentera N, Zinn RA. 2016. Effect of level and source of supplemental tannin on growth performance of steers during the late finishing phase. $\mathrm{J}$ Appl Anim Res. 45:199-203.

Saputra DJ, Ihsan MN, Isnaini N. 2017. Korelasi antara lingkar skrotum dengan volume semen, konsentrasi dan motilitas spermatozoa pejantan sapi Bali. Ternak Tropika. 18:5968.

Standar Nasional Indonesia (SNI). 2015. Bibit sapi potong - Bagian 5: Peranakan ongole. SNI 7651.5:2015. Jakarta (Indonesia): Badan Standardisasi Nasional.

Sugiyono, Susanto A. 2015. Teori dan aplikasi untuk analisis data penelitian. Bandung (Indonesia): Alfabeta.

Suharti S, Astuti DA, Wina E. 2009. Kecernaan nutrien dan performa produksi sapi potong Peranakan Ongole (PO) yang diberi tepung lerak (Sapindus rarak) dalam ransum. JITV. 14:200-207.

Syarifuddin NA, Toleng AL, Rahardja DP, Ismartoyo, Yusuf M. 2017. Improving libido dan sperm quality of Bali bull by supplementation of Moringa oleifera leaves. Media Peternakan. 40:88-93.

Verma AR, Vijayakumar M, Mathela CS, Rao CV. 2009. In vitro and in vivo antioxidant properties of different fractions of Moringa oleifera leaves. Food Chem Toxicol. 47:2196-2201.

Wiyatna MF, Gurnadi E, Mudikdjo K. Produktivitas sapi Peranakan Ongole pada peternakan rakyat di Kabupaten Sumedang. Jurnal Ilmu Ternak. 12:22-25.

Yuliani NY, Dienina DP. 2015. Uji aktivitas antioksidan infusa daun kelor (Moringa oleifera, Lamk) dengan metode 1,1-diphenyl-2-picrylhydaryzl (DPPH). Jurnal Info Kesehatan. 14:1060-1082.

Zurahmah N, The E. 2011. Pendugaan bobot badan calon pejantan sapi Bali menggunakan dimensi ukuran tubuh. Buletin Peternakan. 35:160-164. 